UDC 327(73:416)

DOI: https://doi.org/10.18485/iipe_ria.2021.72.1182.2

Biblid 0543-3657, 72 (2021)

Vol. LXXII, No. 1182, pp. 27-46

Original article

\title{
A VALUABLE PIECE OF THE LIBERAL HEGEMONY PUZZLE: THE UNITED STATES' INVOLVEMENT IN THE NORTHERN IRELAND PEACE PROCESS
}

\author{
Pavle NEDIĆ ${ }^{1}$
}

\begin{abstract}
The conflict in Northern Ireland was resolved with the signing of the Good Friday Agreement in 1998 and with the great involvement of the Clinton administration. The paper explores how the United States (US) efforts in the Northern Ireland peace process contributed to the US grand strategy of liberal hegemony, approaching the subject from a realist perspective and using the method of a case study. It concludes that the Clinton administration saw the potential for a peaceful resolution of this conflict as an important part of its broader efforts to establish a liberal world order in the wake of the ending of the Cold War. This factor was a major motivation for the increased interest of the Bill Clinton administration. The positive outcome of the peace process, which was sponsored and mediated by the US, has become an important foundation for the justification of further engagements supposed to contribute to the liberal hegemony that Clinton's foreign policy aimed to construct.
\end{abstract}

Keywords: Liberal hegemony, US foreign policy, Bill Clinton, Northern Ireland, Good Friday Agreement.

\section{INTRODUCTION}

The Good Friday or the Belfast Agreement was signed on 10 April 1998 and ended decades of conflict and violence in Northern Ireland, known as "the Troubles". The strife between Protestants and Catholics, the unionists and the republicans, traces its origins to the Irish War of Independence, and even further into the past. It was marked by both violent and peaceful protests, political and

\footnotetext{
${ }^{1}$ Research Assistant, Institute of International Politics and Economics, Belgrade. Email: pavle.nedic@diplomacy.bg.ac.rs

The paper presents findings of a study developed as a part of the research project "Serbia and challenges in international relations in 2021", financed by the Ministry of Education, Science, and Technological Development of the Republic of Serbia, and conducted by the Institute of International Politics and Economics, Belgrade.
} 
cultural repression, terrorism and police brutality. However, the end of direct and open violence came with the signing of this peace agreement. The talks between the representatives of the United Kingdom, the Republic of Ireland and major Northern Irish political parties were moderated and chaired by US Senator George J. Mitchell, who was appointed by President Bill Clinton. The US involvement came as a consequence of a wider context. President Clinton's commitment to conflict resolution was an important part of his foreign policy, based on the role of the US as a global promoter of peace in the aftermath of the Cold War.

In this paper, the US contribution to the peace process as a part of Clinton's grand strategy - the creation of global liberal hegemony will be analysed. Relying on the realist approach and the works of Mearsheimer and Walt on liberal hegemony, the paper will explore how the US efforts in the Northern Ireland peace process contributed to this goal. Although the role of the United States in the signing of the Good Friday Agreement is well established, this paper will examine it in the wider context of Washington's grand strategy during the Clinton administration. It will thus contribute to the existing literature both on the subjects of the Northern Ireland conflict and peace process and of the US foreign policy and grand strategy. Temporally, the focus of the paper will be on the first and second presidential terms of Bill Clinton, from 1993 to 2001. Spatially, it will primarily focus on Northern Ireland and the United States, but it will touch upon other regions as well, since its subject is the superpower's grand strategy that, by definition, has a global reach and pretensions. By using Northern Ireland as a case study, the paper aims to show how the US efforts in a specific peace process must be seen from a wider perspective of its grand strategy and previous foreign policy results.

The paper consists of four parts and a conclusion. In the first part of the paper, a literature overview will be given, where the existing research on the concept of liberal hegemony, the conflict in Northern Ireland, the Good Friday Agreement and Clinton's foreign policy will be presented. The second part will provide a brief overview of the Northern Ireland conflict, its history, and the parties involved, as well as a summary of the key provisions of the Good Friday Agreement and an explanation of its significance. In the third part, the role of the US in the peaceful resolution of the conflict in Northern Ireland will be explored. In the fourth part, the US involvement will be analysed as a part of a greater strategy developed by policymakers in Washington, based on the concept of liberal hegemony. Finally, the conclusion will be given.

\section{LITERATURE OVERVIEW}

The concept of liberal hegemony was analysed and its results assessed in detail by the authors from the perspective of the realist school of international 
relations. Mearsheimer (2018) explains what happens when the idea of liberalism, with its emphasis on individual rights, which in turn leads to the preference for democracy and an open market economy, embraces the same principles in its foreign policy. The underlying ideas behind this grand strategy are that individual rights are universal, and a great liberal power has to protect them, that democratic countries do not go to war with each other, and that by promoting liberalism abroad, they are protecting it at home, since non-liberal countries often support domestic anti-liberals (Mearsheimer 2018, 131-136). These ideas lead to the attempts of social engineering across the globe. However, in the absence of a hierarchy in the international system, the great powers are forced to behave in accordance with the realist logic and restrain themselves because other great powers would feel threatened by such a foreign policy. Mearsheimer argues that only in a specific unipolar balance of power can the remaining great power attempt to establish a liberal hegemony unchallenged. Such conditions were created in the aftermath of the Cold War (Mearsheimer 2018, 146). The United States pursued the establishment of liberal hegemony during the height of its unprecedented dominance during the Clinton administration of the 1990s and during the presidential terms of his successors, George W. Bush and Barack Obama, despite the obvious failings of this grand strategy. It leads to militarism, proneness to war as a primary solution, undercuts diplomacy and antagonizes other major powers (Mearsheimer 2018, 159). The author also explains that liberalism at the international level endangers liberalism at home through secrecy, lack of transparency and erosion of civil liberties (Mearsheimer 2018, 185-191).

The reasons behind the continued reliance on liberal hegemony and its less than admirable effects were analysed by Walt (2018). The fall of the USSR gave the United States an opportunity to pursue the grand strategy of liberal hegemony, but America's security, wealth and geostrategic position did not require it. As the author explains, "U.S. primacy made an ambitious grand strategy possible, but it also made it less necessary" (Walt 2018, 15). Liberal hegemony "seeks to expand and deepen a liberal world order under the benevolent leadership of the United States" (Walt 2018, 38). However, it underestimated the antagonism of other major powers to the expanding US influence, over-relied on the results US military power could achieve, misjudged the difficulties and costs of this policy and exaggerated its benefits. Despite the dismal record and numerous unsuccessful initiatives and operations it spawned, the Clinton, Bush and Obama administrations clung to it vehemently (Walt 2018, 14). This is a result of the foreign policy establishment's commitment to this strategy, argues Walt. The ability of the foreign policy community to influence and steer the public debate on these issues has enabled them to present liberal hegemony as the only viable strategy. In this way, they misrepresented the options and influenced the 
decision-making process in a way that they believed was desirable for the US, the world and themselves (Walt 2018, 16).

On the other hand, some authors question the very existence of the liberal international order (LIO) and the liberal hegemony of the United States. Glaser explains that the LIO concept is not useful since it focuses only on the interaction between its member states - liberal democracies, while ignoring the fact that powers such as Russia and China are not part of it (Glaser 2019, 52-53). Moreover, the author argues that "because of weaknesses in three of the mechanisms that constitute the LIO concept-binding, hierarchy, and political convergence - the LIO does not provide the United States with significant indirect security benefits" (Glaser 2019, 65). Offering the critique of the LIO from another angle, Porter argues that the US hegemony is not, in fact, fundamentally different from those that existed throughout history. It is, in its essence, imperial. When it is convenient, "the US, at critical moments, exempts itself from rules and norms, even while preaching them" (Porter 2020, 90). The superpower is ready to wage war in order to promote peace and insists on its own sphere of influence while insisting they are a thing of the past. Thus, in Porter's view, the liberal aspect of the international order does not exist.

It goes without saying that US foreign policy during the Clinton administration was analysed extensively and from multiple perspectives (Warshaw 2004; Lynch 2020). Some authors stamped it with rather negative qualifications due to its reactiveness (Hyland 1999), less than impressive record (Mandelbaum 1996), wrong choice of priorities (Haass 1997) or the President's lack of vision (Foreign policy editors 2000). However, others have made an effort to re-evaluate its effects and results, both on their own and in the context of the policies of the administrations that followed it. Dumbrell $(2005 ; 2009)$ finds that Clinton's foreign policy, framed "between the Bushes", deserves more acknowledgement. Even Walt gave a somewhat apologetic take on Clinton's foreign policy results, taking into account the specific international context the President found himself in (Walt 2000). In particular, his handling of the Northern Ireland conflict was praised (Martin 1999; Dumbrell 2010). The authors also debated at length whether Clinton had a grand strategy and a doctrine, and if he had, were they effective? (Dumbrell 2002, Brands 2008).

The authors also addressed the US involvement in the Northern Ireland conflict during its settlement phase in the 1990s, but also explored the positions of previous administrations on this particular issue although it was never in their foreign policy focus (Thompson 1991). As a superpower whose defining characteristic is its ability to project its influence and power across the globe, a conflict directly involving one of its main and crucial allies, the United Kingdom, had to be of interest to foreign policy makers in Washington, independently of other issues they had to deal with. The influence of the Irish-American 
communities, especially Catholics, and organizations, such as the Irish Northern Aid Committee (NORAID) and the Ancient Order of Hibernians (AOH), in both the peace efforts and the protraction of the conflict has been explored, as well as the position of the Nixon and Carter administrations, which were mainly indifferent to it (Dumbrell 1995). The increased US interest during Ronald Reagan's presidency and his contribution to the securing of the Anglo-Irish Agreement of 1985 were also acknowledged (Cooper 2017). Expectedly, due to his important role, Bill Clinton's involvement was written about in great detail as well (MacGinty 1997; Wilson 1997; Cox 1999; Hazleton 2000). Other authors focused on US economic support in this period (Wilson 2001; White 2018). The important function of the moderator and the personal touch Senator Mitchell brought to the negotiation is another important factor that was covered by scholars (Curran et al. 2004). Although often neglected to be mentioned, due to the significance the invasions of Afghanistan and Iraq conducted in his term had on international relations, the contribution of Clinton's successor, George W. Bush, to the peace process in Northern Ireland and the enforcement of the Good Friday Agreement was also the subject of scientific interest (Marsden 2006; Clancy 2007).

The Good Friday Agreement, which brought an immediate resolution to the violence between the varying factions in Northern Ireland, the unionists and the Irish nationalists, was compared and analysed in juxtaposition with the failed Sunningdale Agreement of 1973 (Tonge 2000). The road to peace and the necessary conditions which led to the signing of the Good Friday Agreement in 1998 were also of interest to scholars (Wolff 2001), as well as the ways in which it changed the structure of the conflict by enabling the British to reposition themselves (Todd 2003). Furthermore, it was also researched how the signing parties were able to convince the population on both sides to accept the agreement by presenting it as the less risky option (Hancock et al. 2010). McGarry (2001; 2002) focused on the political institutions stemming from the agreement and gave a detailed analysis of Northern Ireland as a model of consociational democracy, first developed by Arend Lijphart. Additionally, peace studies researchers studied the Northern Ireland conflict and its peaceful solution as a learning process (Tannam 2001) and an example of path dependency (Ruane and Todd 2007). Of course, due to the perceived effectiveness of this particular conflict resolution, the lessons learned from it and their potential implementation in other conflict cases were examined as well (White 2013).

So, the Northern Ireland conflict is a hot topic in the scientific disciplines of international relations, peace studies and security studies. The foreign policy of the Clinton administration, in general, has also been vastly discussed, debated and analysed. However, the conflict, its resolution and decisive role the United States interest had in it have not garnered much scientific attention from the 
scholars dealing with topics of the US foreign policy, the US grand strategy, international relations in the immediate period after the end of the Cold War and researchers interested in the US sponsored and supported efforts to establish liberal hegemony during the 1990s. Both the US military and peace involvement in conflicts and its interventionism during this period have been the subject of great, thorough and insightful analysis and scientific research. Many papers and books were written about the humanitarian intervention in Somalia in 1992-1993 (Clark 1992; Clarke and Herbst 1996; Klarevas 2000) in which the US role was crucial, or the decisive influence of Washington on the developments and ultimate settlement of the wars in the Balkans (Varadarajan 1999), primarily in Bosnia and Herzegovina (Sobel 1998) and Kosovo and Metohija (Henkin 1999). Yet, although the United States contributed greatly to the peace process in Northern Ireland and, all things considered, their involvement can be characterized as a successful one, which is not the attribute given without hesitation to some of the aforementioned operations, it did not warrant detailed analysis in the context of the US grand strategy of the 1990s, and that of the Clinton administration specifically. The paper will present the US role in the settlement of the conflict in Northern Ireland in this context. It will explore how can the contribution of Bill Clinton be understood as a part of his approach to the US foreign policy and the wider international relations goals of his administration, namely the achievement of global liberal hegemony, led by the United States, which is unburdened by a rival ideology with whom it must compete for world domination. The paper will argue that the US support for the signing of the Good Friday Agreement and the negotiations that led to it was an important piece of these efforts. But first, a brief history of the conflict in Northern Ireland will be presented in order to better understand the causes and roots of this decades-spanning cycle of violence and political struggle.

\section{THE CONFLICT IN NORTHERN IRELAND: A BRIEF HISTORY}

The conflict in Northern Ireland has its roots in a history of conquest, oppression, rebellions and competing visions of the future of the northern part of the island. The basis for the English conquest of Ireland can be traced to the papal bull Laudabiliter issued in 1155 by the only English Pope, Adrian IV, which granted the right to the king Henry II to invade and rule the Irish island (Beggan and Indurthy 1999, 4). In the subsequent centuries, English forces took control of the whole of Ireland. James I started the settlement of Protestants in the northern part of the island - Ulster in the seventeenth century and forced out the Catholic Irish living there. The process was intensified during the reign of Lord Protector Oliver Cromwell. The incoming English settlers were large 
landowners, so the social cleavage that was created divided the people across national, religious and class lines. The Irish struggle and desire for independence resulted in an unsuccessful rebellion at Easter 1916, which led to the Irish War of Independence of 1919-1921. The result of the Irish Republican Army (IRA) campaign was an Irish Free State, which severed all ties with Britain and the Commonwealth after the referendum and the declaration of the Republic in 1937. However, this state did not encompass the whole island.

Northern Ireland was formed in the northern part of the island by the British from six of the nine counties of the Ulster province. Besides the four counties with a predominantly Protestant population (Antrim, Armagh, Down and Londonderry), it also includes the two with the most prominent Protestant minority (Fermanagh and Tyrone), which meant that at the time of its creation, two-thirds of the Northern Irish population were Protestants and one-third were Catholics (Beggan and Indurthy 1999, 6). This created a suitable situation for continuous strife and conflict, further incited by the discrimination of the Catholic minority in the aspects of political representation, employment and housing (Dorney 2015). The following decades created two opposing ideas that became deeply embedded in their respective communities. Protestants were mainly in favour of unionism and remaining firmly in the United Kingdom, while Catholics predominantly favoured republicanism and pushed for independence from the British Crown and unity with the Republic of Ireland.

In the late 1960s, inspired by the civil rights movement in the United States, the Northern Ireland Civil Rights Association was founded. Its goal was to fight for the end of discrimination against the Catholic part of the population. Their protests and marches often led to violence due to attacks of the unionists. The culmination was the riots of August 1969, which resulted in eight deaths and numerous people being injured and displaced, houses burned and neighbourhoods destroyed (Dorney 2015). This sparked the deployment of the British Army in order to restore order, which was initially welcomed by Catholics since it meant the end of the current violence.

The riots were a preview of the 1970s, which were the most violent and bloody decade in the Northern Irish conflict (Dorney 2015). The Provisional IRA detached from the original organization in order to fight for a united Ireland through a campaign of violence and terrorism. The unionists had their own paramilitary organizations, such as the Ulster Defence Association (UDA) and the Ulster Volunteer Force (UVF), which organized attacks on both the IRA and civilian targets and used indiscriminate methods to wage war for the cause of unionism. "The Troubles" drove the British Government to abolish Northern Irish autonomy in 1972 and govern the province directly from London, primarily through the office of the Secretary of State for Northern Ireland. The British policies during the 1970s and 1980s led to further divisions and enforced the 
determination of the republicans. For example, the British Parliament passed the Prevention of Terrorism Act in 1974, which allowed the authorities to hold a suspect for up to seven days without any charge. The government of Margaret Thatcher removed the political status of the IRA prisoners and treated all the IRA actions as criminal and not as political acts. In protest, many imprisoned IRA members went on hunger strikes, often with fatal outcomes (Beggan and Indurthy 1999, 10-11).

Despite all the violence, the 1970s and 1980s also brought two important initiatives which were aimed at finding a permanent solution to the situation in Northern Ireland. The first one was the Sunningdale Agreement of 1973. The crucial aspect was the creation of the Council of Ireland, which was to be formed of an equal number of representatives of legislative and executive from Northern Ireland and the Republic of Ireland. The Council was supposed to manage the policy areas of common interest for the whole island, but it was never constituted and the agreement collapsed. The unionists were fervently opposed to this concept and felt betrayed by the Labour government in London (Wolff 2001, 166). They organized massive strikes led by the leader of the Democratic Unionist Party (DUP), the Reverend Ian Paisley. The second initiative was the Anglo-Irish Agreement of 1985. It was signed by the British and Irish Prime Ministers. The Agreement established a joint intergovernmental conference which was supposed to give the Republic of Ireland a consultative role in the internal affairs of Northern Ireland and address some of the Catholic grievances, primarily in the security sector (Coakley 2001, 13). The unionists were again opposed and led a successful "Ulster Says No" campaign against it. Although the results of the aforementioned initiatives were questionable or downright non-existent, both agreements were important in paving the road for the one that would succeed in the future. This could be said of the Anglo-Irish Agreement, in particular, because it allowed London and Dublin to collaborate to find a solution to the Northern Ireland situation.

The conditions for the negotiations started to form in the 1990s. A favourable international context in the wake of the end of the Cold War, on the one hand, and the prolonged nature of the fighting that left both sides in a stalemate, on the other, made a resolution by compromise an achievable and not an unwelcomed result. In 1994, first the IRA and then the unionist paramilitary organizations proclaimed a ceasefire and a series of negotiations and peace talks started with a diverse group of actors and in a series of various configurations and phases (Coakley 2001, 15). In the negotiations were represented, among others, the British and Irish governments, more moderate parties such as the Ulster Unionist Party (UUP) and the republican Social Democratic and Labour Party (SDLP), as well as Sinn Féin, the political wing of the IRA. The DUP, which was present at the start, left the negotiations after the inclusion of Sinn 
Féin. The talks were moderated by US Senator George J. Mitchell, appointed by the US President, Bill Clinton. The final text of the Good Friday or the Belfast Agreement, signed on 10 April 1998, was deliberately vague and ambiguous in order to be acceptable to all sides. According to the agreement, Northern Ireland's constitutional status would be decided solely by the democratic vote of its inhabitants, recognizing that the majority of its people want to remain in the United Kingdom. The provisions included dual citizenship, a proportionally elected legislative body, an executive led by the Prime Minister and Deputy Prime Minister, who come from different communities, an Anglo-Irish intergovernmental conference and a North-South ministerial council (Coakley 2001, 17-19). The paramilitary groups were to disarm and prisoners would be granted an early release. The Agreement was confirmed in a referendum in Northern Ireland, followed by a successful referendum in the Republic of Ireland to remove the claim to Northern Ireland from its constitution, which was also stipulated in the document. The referendums gave the people a sense of ownership of the process (Wolff 2001, 169). Although the following years showed the implementation of the Good Friday Agreement was a slow and hard process, it did effectively put an end to "the Troubles" in Northern Ireland. What was the role of the US in this peace process? In the next part, this aspect, especially in the context of the American grand strategy, will be analysed.

\section{THE US INVOLVEMENT IN THE NORTHERN IRELAND PEACE PROCESS}

Although the conflict and the violence in Northern Ireland were a continuous and ever-present issue, the US administrations in the 1970s and 1980s were not very interested in taking any steps to influence the situation there. President Jimmy Carter, whose whole foreign policy was framed around the issue of human rights, made an unexpected exception in 1977 when he gave a statement about potential increased US investment in Northern Ireland if a peaceful solution was achieved (Dumbrell 2018, 116). Still, he limited his response to this remark. President Ronald Reagan's contribution, on the other hand, was most felt during the talks which resulted in the signing of the Anglo-Irish Agreement of 1985. He discussed the issue with Prime Minister Thatcher in order to nudge her to be more willing to consider a possible deal (Dumbrell 2018, 119). Despite the fact that his intervention was successful, the US showed little interest in getting more actively engaged. The main channel through which the Northern Ireland conflict was put on the table of US politics was the campaigns and lobbying of the socalled Four Horsemen - Speaker of the House of Representatives Tip O'Neil, Senator Edward Kennedy, Senator Daniel Patrick Moynihan and Governor of New York Hugh Carey (White 2018, 6). The considerable influence of these 
politicians and their sympathy for the idea of a united Ireland, along with the efforts of American-Irish interest groups, such as the AOH and the NORAID, managed to make a case for the republican cause relatively successfully. The Four Horsemen put pressure on both Carter and Reagan to engage in some capacity, which resulted in the mentioned actions. However, the executive branch remained largely uninterested in the developments in what it considered an internal issue of the United Kingdom. American disinterest is best illustrated by the fact that the State Department traditionally assigned a junior Foreign Service Officer (FSO) to the Ireland-Northern Ireland-Iceland Desk, who always deferred to a Senior FSO at the British Desk since Northern Ireland is a part of the UK (Thompson 1991, 104). This general inactivity regarding the Northern Ireland conflict was to change rather drastically under President Bill Clinton.

Bill Clinton first became associated with the Northern Ireland issue during his presidential election campaign and fundraising activities. During the forum for Irish issues held in the Sheraton Hotel in Manhattan in April 1992, the future President gave several replies about his actions regarding Northern Ireland. In order to win the support of the influential American Irish Catholic community, Clinton promised to grant a US visa to the IRA leader, Gerry Adams, who was denied this document on several previous occasions. He also pledged to send a special envoy to Northern Ireland (Beggan and Indurthy 1999, 13-14). After winning the election and becoming President, Clinton came into a situation where he could make good on his promises. While his special envoy idea never gathered much support from either the community in Northern Ireland or the British and Irish governments, the potential visa for Gerry Adams was seen as an important signal. The President declined to grant it to the IRA leader in 1993. However, the following year, he changed his decision (Cox 1997, 687). This change caused great controversy and dissatisfaction in Britain, but it turned out to be one of the better judgment calls by President Clinton and influenced the prospective negotiations greatly. Disregarding the opinions on the matter of the CIA, the FBI and the State Department, he followed the advice of his National Security Advisor, Anthony Lake, and the Deputy Assistant to the President for National Security Affairs, Nancy Soderberg. They framed the situation as a win-win scenario for the president, and he decided to take a gamble (Cox 1999, 63-64). The visa was given with expectations of the IRA ceasefire in return. They reasoned that if Adams delivered this result, it would be a diplomatic victory. If he did not, the IRA would be exposed as untrustworthy and lose its credibility. The gamble paid off. The position in the organization of the moderate Gerry Adams was strengthened with this move and contributed to his successful push against the more radical IRA members. As a result, the unilaterally declared ceasefire in 1994 was the start of a negotiation process that led to the Good Friday Agreement four years later. 
The incentives for the IRA by the Clinton administration to remain committed to negotiations and the quest for a peaceful solution continued in the following years. Adams was granted a visa again in 1995 and met with President Clinton at the celebration of Saint Patrick's Day in the White House. Moreover, the IRA was given permission to fundraise in the United States, despite strong opposition from the British (Wilson 1997, 33). UK Prime Minister John Major was reportedly so aggravated that he declined calls from Clinton for a week (MacGinty 1997, 6). Still, the more active role the US has taken enabled the unprecedented meeting of the Secretary of State for Northern Ireland, Patrick Mayhew, and Gerry Adams at the Investment Conference in Washington in May 1995 (Wilson 1997, 33). This remarkable encounter was an important factor in the normalization of regular contacts between all sides in order to find a solution.

Clinton's visit to London, Belfast, Derry and Dublin in late 1995 with his wife Hilary was a culmination and a high-point of the President's commitment to the Northern Ireland conflict resolution. The significance of the visit stems from the renewed sense of progress and concrete events it inspired in the population. On the other hand, it was a significant step in the process of convincing the unionist that the US is not one-sided in its approach to this conflict and has no favourites. As unionist Roy Bradford commented on the importance of Clinton's visit, it "significantly changed the feeling among unionists that the American agenda is exclusively nationalist" (as quoted in MacGinty 1997, 8). The exception was the reaction and stance of Ian Paisley and the DUP. The ceasefire broke down in 1996 and Clinton was focused on the elections back home, but his dedication to the peace process remained, evident in the appointment of former Senate majority leader George J. Mitchell as chair of the multi-party peace talks in June of the same year (MacGinty 1997, 9), which followed his earlier appointment as a Special Envoy for Northern Ireland in December 1994 (Dumbrell 2018, 124).

The Senator's role was crucial, as his fair and balanced approach enabled all sides to have confidence in his handling of the talks. He successfully navigated difficult and sensitive topics and focused on achieving results in the areas that all parties could agree upon at the time. Still, behind him, there was always Clinton and his genuine will to contribute to the solution. The gravity President's interest brought to negotiations cannot be overstated. When the outline of the document was drafted and an end was visible on the horizon, he made himself available constantly to the participants via phone. These phone consultations were instrumental in convincing Taoiseach (Irish Prime Minister) Bertie Ahern when he was having second thoughts about the proposed agreement. Clinton was also able to persuade the UUP and SDLP leaders, David Trimble and John Hume, to accept the agreement, although they had serious reservations. Trimble especially faced grave opposition within his party about the concessions he made, so the 
President's encouragement and persuasiveness were essential (White 2018, 8). The result of these combined undertakings of all parties involved was the peace in Northern Ireland, which has lasted for more than 20 years. It is doubtful if the peace talks would have resulted in an agreement there and then without the Clinton administration's dedication to it.

\section{NORTHERN IRELAND IN THE CONTEXT OF THE US GRAND STRATEGY}

The US involvement in Northern Ireland can be characterized as an "encouragement from the sidelines" (Hazleton 2000) and that it was "regularized, though not institutionalized" (MacGinty 1997, 7). Different factors contributed to Clinton's interest in this issue and the active role he took. He initially looked at securing the important American Irish vote in the elections of 1992. His closeness to the Kennedy family also played a role. Clinton relied heavily on Senator Edward Kennedy for advice and appointed his sister, Jean Kennedy Smith, as the US ambassador to Ireland in 1993 (Cox 1999, 63). Furthermore, his decision to disregard the British complaints regarding the Gerry Adams visa was also influenced by his contempt for the Conservatives and John Major because they actively worked to help the Bush campaign in 1992 (Beggan and Indurthy 1999, 14). However, a very important factor of his involvement is the larger international context and the US foreign policy of the time, primarily shaped by the grand strategy of liberal hegemony.

In the aftermath of the Cold War, the position of the US as the sole remaining superpower enabled it to embark on a reordering at the international level to its preferences. The balance of power that existed in the bipolar world during the previous 45 years has ceased to exist. Even during the period of the Cold War, the Northern Ireland issue was decidedly in the US sphere of influence, although its interest in the conflict was rather limited, as previously explained. The IRA was in part inspired by the wider revolutionary struggles around the world, with the battle between capitalism and communism in the background (Cox 1997, 677). The change in the global framework affected the organization and prompted the increase of US interest. So, the involvement of the US was intensified in the period when the country was more than ever able to act and intervene without the significant opposition of other powers since Russia was adapting to its new role in the aftermath of the USSR collapse and China was focused inward on its economic development. On the regional level, the involvement in the Northern Ireland peace process confirmed the dominant position of the US in the "special relationship" with the UK. Additionally, it emphasised the role of the US as the security provider for Europe and asserted its commitment to European affairs even without the threat of communism and 
the forces of the USSR. This stance was also evident in the US grand strategy of the period.

The grand strategy of the Clinton administration was outlined by the National Security Advisor, Anthony Lake, in his speech given at John Hopkins University on 21 September 1993 and further elaborated by the President in his address to the United Nations General Assembly on 27 September 1993 (Brinkley 1997, 115). In 1994, the crucial principles and ideas were laid out in the new National Security Strategy of Engagement and Enlargement (Brinkley 1997, 120). The document primarily stems from the new role and position of the United States in the post-Cold War world. Through its basis in the liberal values of free trade and democracy as foundations for a more prosperous and secure world, it was the groundwork for the pursuit of liberal hegemony, the central concept that drove the foreign policy of both Clinton and his successors. Observing the Northern Ireland case through the prism of grand strategy is useful in three aspects. Firstly, taking into account that economic development is one of the founding principles of liberal hegemony, the considerable emphasis that the US has placed on this component of its support can be understood. Secondly, putting the success in Northern Ireland into a wider perspective shows its use as a positive example and argument for involvement in other conflicts, namely in the Balkans and the Middle East, during the Clinton administration and those of his successors. Thirdly, it shows that the positive result can in part be attributed to the minimalistic approach taken and the commitment to be as neutral as possible.

Regarding Northern Ireland, the domestic focus on the economy in the US was followed by the application of a similar approach to foreign policy. It was in line with the idea of economic interdependence, which is one of the main pillars of the concept of liberal hegemony (Mearsheimer 2018, 195). It is based on the belief that the economic development, in significant part stimulated by foreign investment, will lead to trade and economic links which will make the war harder and the cost of conflict too high. With this logic in mind, the economic dimension of US involvement in Northern Ireland has become considerable. Before being appointed Special Envoy, Mitchell was a special presidential adviser on economic initiatives for Northern Ireland, while Nancy Soderberg chaired a committee which was examining potential economic initiatives (MacGinty 1997, 7). Several delegations visited Northern Ireland to investigate opportunities for investment, including two led by US Commerce Secretary Ron Brown in 1994 and 1995 (Wilson 2003, 160). Additionally, Clinton increased the annual US contribution to the International Fund for Ireland from 20 million dollars to 30 million (MacGinty 1997, 7).

However, Clinton's foreign policy approach in the first period of his presidential term was not marked by a clear adherence to any strategy or plan. It was reactive and constantly modified on a case-by-case basis. He committed the 
US troops to the UN peacekeeping mission in Somalia. They were the linchpin of the operation, since the UN relied on the American presence as the backbone of the humanitarian intervention. Shortly after the killings of 18 US Army Rangers in Mogadishu in October 1993, Clinton withdrew the American forces from the country (Lynch 2020, 61). The humanitarian crisis in Haiti, caused by brutal reprisals after a forceful regime change in a country not far from US soil, prompted the President to send in the USS Harlan County in October 1993, barely a week after the Mogadishu firefight. But after the protest by the local population on the docks, the ship turned away and returned to its homeport (Lynch 2020, 63). These failings caused the administration's reluctance to engage in Rwanda and potentially stop the genocide or lessen the number of perpetrated mass killings. The feeble initial foreign policy results led to the recognition of the Northern Ireland conflict as a chance to finally achieve some tangible and worthy results.

After a series of unsuccessful endeavours, the President needed a breakthrough on some foreign policy fronts. The conflict in Northern Ireland was recognized as an opportunity for a relatively easy score. The potential costs were comparatively small and acceptable. The unavoidable disturbance of the "special relationship" with London did not carry as much weight as it did during the Cold War. As Clinton said, "I think sometimes that we are too reluctant to engage ourselves in a positive way because of our long-standing special relationship with Great Britain" (as quoted in Cox 1997, 686). The changing international context meant that the good terms with their traditional ally across the Atlantic could suffer a moderate setback without serious or long-lasting consequences. The administration's involvement and the peaceful resolution of the decades-long violence it would stimulate were expected to justify the further engagement in other conflicts and parts of the world, such as the Balkans and the Middle East. It must not be overlooked that they were much more important to the US interests than the situation on the Irish island, but the support for this kind of entanglement was rather reluctant. The Balkans was an opportunity to assert the American commitment to Eastern Europe and confirm that the only remaining global superpower is fully committed to its newly acquired allies, in the wake of the emerging process of NATO enlargement. The approach to this issue was a test of NATO's credibility and Clinton's statesmanship (Lynch 2020, 73). The Middle East was a traditionally important region due to its oil and geostrategic position and has become increasingly unstable due to the struggles for regional supremacy among its main actors. Also, it was the main source of the developing threat of terrorism, although that significance was not fully comprehended at the time. The positive result in Northern Ireland gave considerably more weight to a more active and continual US role in these regions.

Finally, the success of the Northern Ireland case was in part due to the restraint that the US showed in this particular instance. The more comprehensive 
involvement and attempts to achieve a deep reform of the whole country and society proved very difficult and result questionable, especially during the international undertakings of Clinton's successors. On the other hand, the minimalistic approach which was taken in Northern Ireland and the genuine commitment to be as neutral and impartial as possible gave credibility to American inclusion as an important factor in the process. The confirmation came when George J. Mitchell was called again to Northern Ireland to help mediate an impasse in the decommissioning process and the formation of a powersharing executive (Beggan and Indurthy 1999, 17). Part of the success in Northern Ireland can be contributed to the US reluctance to "try to impose solutions on others solely by issuing ultimatums and ratcheting up more and more pressure" (Walt 2018, 56). So, because the US did not apply all the regular methods it relied upon in the creation of liberal hegemony, the accomplishment in Northern Ireland was easier to achieve. Paradoxically, that accomplishment gave justification and a precedent for the later ventures which ended up more or less unsuccessfully, in part because the positive example of Northern Ireland was not relied upon more closely as a blueprint.

\section{CONCLUSION}

The establishment of liberal hegemony was a leading idea and rationale behind the decisions of foreign policy makers in the United States during the last decade of the twentieth century and at the beginning of the twenty-first century. For the US, the undisputed victor of the Cold War, the space for the reshaping of the international order at its will has been opened. The conflict in Northern Ireland, whose roots and causes trace back to history, in this new international context, was a great opportunity for larger American involvement. The previous administrations treated it as a British internal issue, but President Bill Clinton showed great personal interest and dedication to a peaceful solution to the conflict between the unionists and the republicans. Taking a calculated risk with the visa for the IRA leader Gerry Adams in 1994, he stimulated the creation of necessary conditions for the ceasefire and negotiations. Furthermore, his commitment, demonstrated during the peace talks and the appointment of Senator Mitchell as a Special Envoy to Northern Ireland, who greatly influenced the peace process, contributed to the solution in the form of the Good Friday Agreement. The American role was also evident in the economic stimulus supposed to induce the people of Northern Ireland, while the President's attentiveness can be further comprehended in the wake of his previous international undertakings. He needed a relatively easy win on the foreign policy front to mitigate the damage of these failings, at the same time providing a justification for future engagements in other regional conflicts more important 
for the US strategic interests. Hence, the US involvement in Northern Ireland presented an important and overlooked part of the wider pursuit of liberal hegemony creation, which started during the two presidential terms of President Bill Clinton.

\section{REFERENCES}

Beggan, Dominic and Rathnam Indurthy. 1999. "The Conflict in Northern Ireland and the Clinton Administration's Role". International Journal on World Peace 16 (4): 3-25.

Brands, Hal. 2008. From Berlin to Baghdad: America's Search for Purpose in the Post-Cold War World. Lexington: University Press of Kentucky.

Brinkley, Douglas. 1997. "Democratic Enlargement: The Clinton Doctrine". Foreign Policy 106: 110-127. https://doi.org/10.2307/1149177

Clancy, Mary Alice C. 2007. "The United States and Post-Agreement Northern Ireland, 2001-6". Irish Studies in International Affairs 1: 155-173.

Clark, Jeffrey. 1992. "Debacle in Somalia". Foreign Affairs 72 (1): 109-123. https://doi.org/10.2307/20045500

Clarke, Walter and Jeffrey Herbst. 1996. "Somalia and the Future of Humanitarian Intervention". Foreign Affairs 75 (2): 70-85. https://doi.org/10.2307/20047489

Coakley, John. 2001. "Ethnic Conflict and its Resolution: The New Northern Ireland Model". Revised version of a paper presented at the Colloquium of the Research Committee on Politics and Ethnicity of the International Political Science Association, Patiala, India, January 6-8.

Cooper, James. 2017. "The Situation over There Really Bothers Me': Ronald Reagan and the Northern Ireland Conflict". Irish Historical Studies 41 (159): 97-116. https://doi.org/10.1017/ihs.2017.3

Cox, Michael. 1997. "Bringing in the 'International': The IRA Ceasefire and the End of the Cold War". International Affairs 73 (4): 671-693. https://doi.org/10.2307/2624463

Cox, Michael. 1999. "The War That Came in from the Cold: Clinton and the Irish Question”. World Policy Journal 16 (1): 59-67.

Curran, Daniel, James K. Sebenius and Michael Watkins. 2004. "Two Paths to Peace: Contrasting George Mitchell in Northern Ireland with Richard Holbrooke in Bosnia-Herzegovina". Negotiation Journal 20 (4): 513-537. https://doi.org/10.1111/j.1571-9979.2004.00041.x 
Dorney, John. 2015. "The Northern Ireland Conflict 1968-1998: An Overview", The Irish Story, February 9. https://www.theirishstory.com/2015/02/09/thenorthern-ireland-conflict-1968-1998-an-overview/\#.YCBP449Kjcv

Dumbrell, John. 2002. "Was There a Clinton Doctrine? President Clinton's Foreign Policy Reconsidered". Diplomacy \& Statecraft 13 (2): 43-56. https://doi.org/10.1080/714000309

Dumbrell, John. 2005. "Evaluating the foreign policy of President Clinton, or Bill Clinton: between the Bushes". Paper presented at the British Association for American Studies Annual Conference, Cambridge University, Cambridge, April 14-17.

Dumbrell, John. 2009. Clinton's Foreign Policy: Between the Bushes, 1992-2000. Abingdon, Oxon: Routledge.

Dumbrell, John. 2010. "President Bill Clinton and US Transatlantic Foreign Policy". Journal of Transatlantic Studies 8 (3): 268-278. https://doi.org/ 10.1080/14794012.2010.498128

Dumbrell, John. 2018. "The United States and the Northern Irish Conflict 196994: From Indifference to Intervention”. Irish Studies in International Affairs 6: 107-125. https://www.jstor.org/stable/30001841

Foreign policy editors. 2000. "Clinton's Foreign Policy". Foreign Policy 121: 18-29. https://doi.org/10.2307/1149615

Glaser, Charles L. 2019. "A Flawed Framework: Why the Liberal International Order Concept Is Misguided”. International Security 43 (4): 51-87. https://doi.org/10.1162/ISEC_a_00343

Haass, Richard N. 1997. "Fatal Distraction: Bill Clinton's Foreign Policy”. Foreign Policy 108: 112-123. https:// doi.org/10.2307/1149093

Hancock, Landon E., Joshua N. Weiss and Glen M. E. Duerr. 2010. "Prospect Theory and the Framing of the Good Friday Agreement". Conflict Resolution Quarterly 28 (2): 183-203. https://doi.org/10.1002/crq.20019

Hazleton, William. 2000. "Encouragement from the Sidelines: Clinton's Role in the Good Friday Agreement". Irish Studies in International Affairs 11: 103-119.

Henkin, Louis. 1999. "Kosovo and the Law of 'Humanitarian Intervention"'. The American Journal of International Law 93 (4): 824-828. https://doi.org/ $10.2307 / 2555346$

Hyland, William G. 1999. Clinton's World: Remaking American Foreign Policy. Westport, CT: Praeger Publishers.

Klarevas, Louis J. 2000. "Trends: The United States Peace Operation in Somalia". The Public Opinion Quarterly 64 (4): 523-540. https://www.jstor.org/ stable/3078741 
Lynch, Timothy J. 2020. In the Shadow of the Cold War: American Foreign Policy from George Bush Sr. to Donald Trump. Cambridge: Cambridge University Press.

MacGinty, Roger. 1997. "American Influences on the Northern Ireland Peace Process". Journal of Conflict Studies 17 (2).

Mandelbaum, Michael. 1996. "Foreign Policy as Social Work". Foreign Affairs 75 (1): 16-32. https://doi.org/10.2307/20047465

Marsden, Lee. 2006. "Promoting Democracy in Northern Ireland: George Bush and the Peace Process". The Political Quarterly 77 (1): 61-70. https://doi.org/10.1111/j.1467-923X.2006.00731.x

Martin, Jurek. 1999. "Clinton Abroad”. The Washington Monthly 31 (3): 22-26.

McGarry, John. 2001. "Consociational Theory and Northern Ireland's Good Friday Agreement". European Yearbook of Minority 1 (1): 283-298. https://doi.org/10.1163/221161102X00121

McGarry, John. 2002. "'Democracy' in Northern Ireland: Experiments in SelfRule from the Protestant Ascendancy to the Good Friday Agreement". Nations and Nationalism 8 (4): 451-474. https://doi.org/10.1111/14698219.00061

Mearsheimer, John J. 2018. The Great Delusion: Liberal Dreams and International Realities. New Haven, CT: Yale University Press.

Porter, Patrick. 2020. The False Promise of Liberal Order: Nostalgia, Delusion and the Rise of Trump. Cambridge: Polity Press.

Ruane, Joseph and Jennifer Todd. 2007. "Path Dependence in Settlement Processes: Explaining Settlement in Northern Ireland”. Political Studies 55 (2): 442-458. https://doi.org/10.1111/j.1467-9248.2007.00623.x

Sobel, Richard. 1998. "Trends: United States Intervention in Bosnia". The Public Opinion Quarterly 62 (2): 250-278. https://www.jstor.org/stable/2749625

Tannam, Etain. 2001. "Explaining the Good Friday Agreement: A Learning Process". Government and Opposition 36 (4): 493-518. https://doi.org/10.1111/ 1477-7053.00078

Thompson, Joseph E. 1991. "U.S. Interest and Involvement in Ireland and Northern Ireland". Études Irlandaises 16 (2): 103-117. https://doi.org/ 10.3406/irlan.1991.1018

Todd, Jennifer. 2003. "The Changing Structure of Conflict in Northern Ireland and the Good Friday Agreement". Paper presented to the IBIS conference Renovation or Revolution? New territorial politics in Ireland and the United Kingdom, University College, Dublin, April 3. 
Tonge, Jonathan. 2000. "From Sunningdale to the Good Friday Agreement: Creating Devolved Government in Northern Ireland". Contemporary British History 14 (3): 39-60. https://doi.org/10.1080/13619460008581593

Varadarajan, Siddharth. 1999. "The Politics of Military Intervention: NATO's Operations in Yugoslavia”. India International Centre Quarterly 26 (2): 101-113. https://www.jstor.org/stable/23005662

Walt, Stephen M. 2000. “Two Cheers for Clinton's Foreign Policy”. Foreign Affairs 79 (2): 63-79. https://doi.org/10.2307/20049641

Walt, Stephen M. 2018. The Hell of Good Intentions: America's Foreign Policy Elite and the Decline of U.S. Primacy. New York: Macmillan.

Warshaw, Shirley Anne. 2004. The Clinton Years. New York: Facts On File.

White, Timothy J. 2013. "Learning from the Northern Ireland Peace Process: Sui Generis and Broader Lessons?". Paper Presented at the Annual Meeting of the American Conference for Irish Studies, Chicago, Illinois, April 13.

White, Timothy J. 2018. "American Diplomacy and Economic Aid in the Northern Ireland Peace Process: A Neoliberal Analysis". Open Library of Humanities 4 (1): 1-19. https://doi.org/10.16995/olh.255

Wilson, Andrew J. 1997. "From the Beltway to Belfast: The Clinton Administration, Sinn Féin, and the Northern Ireland Peace Process". New Hibernia Review/Iris Éireannach Nua 1 (3): 23-39.

Wilson, Andrew J. 2001. "The Irish Peace Process and Cultural Training Program Act 1998 (Walsh Visa Program): A Case Study in Us Economic Support for the Good Friday Agreement". Irish Political Studies 16 (1): 245-256. https://doi.org/10.1080/07907180108406644

Wilson, Andrew J. 2003. “'Doing the Business': Aspects of the Clinton Administration's Economic Support for the Northern Ireland Peace Process, 1994-2000". Journal of Conflict Studies 23 (1).

Wolff, Stefan. 2001. "The Road to Peace? The Good Friday Agreement and the Conflict in Northern Ireland”. World Affairs 163 (4): 163-170. 


\section{VAŽAN DEO U SLAGALICI LIBERALNE HEGEMONIJE: UKLJUČENOST SJEDINJENIH AMERIČKIH DRŽAVA U MIROVNI PROCES U SEVERNOJ IRSKOJ}

Apstrakt: Sukob u Severnoj Irskoj je okončan potpisivanjem Sporazuma na Veliki Petak 1998. godine uz značajno uključivanje Klintonove administracije. Rad istražuje na koji je način uticaj Sjedinjenih Država na mirovni process u Severnoj Irskoj doprineo američkoj velikoj strategiji liberalne hegemonije, prilazeći temi iz ugla teorije realizma i koristeći metodu studije slučaja. Zaključuje se da je Klintonova administracija videla potencijal za mirovno rešenje ovog sukoba kao važan deo širih napora da uspostavi liberalni svetski poredak nakon završetka Hladnog rata. Ovaj faktor je doprineo motivaciji za povećano interesovanje administracije Bila Klintona. Pozitivan rezultat mirovnog procesa, koji su podržale i u kojem su posredovale $\mathrm{SAD}$, postao je važna osnova za opravdavanje budućih interevencija u cilju doprinesa stvaranju liberalne hegemonije kojoj je težila Klintonova spoljna politika.

Kjučne rečr: liberalna hegemonija, spoljna politika SAD, Bil Klinton, Severna Irska, Sporazum na Veliki petak.

Received: 07.04.2021

Accepted: 14.07.2021 